\title{
The Ink4a/Arf Locus Is a Barrier to Direct Neuronal Transdifferentiation
}

\author{
James D. Price, ${ }^{1,2,3 *}$ Ki-Youb Park, ${ }^{1,3 *}$ Jiadong Chen, ${ }^{1,4}$ Ryan D. Salinas, ${ }^{1,3}$ Mathew J. Cho, ${ }^{1,3}$ Arnold R. Kriegstein, ${ }^{1,4}$ \\ and Daniel A. Lim ${ }^{1,2,3,5}$ \\ ${ }^{1}$ Eli and Edythe Broad Center of Regeneration Medicine and Stem Cell Research, ${ }^{2}$ Developmental and Stem Cell Biology Graduate Program, ${ }^{3}$ Department of \\ Neurological Surgery, ${ }^{4}$ Department of Neurology, and ${ }^{5}$ San Francisco Veterans Affairs Medical Center, University of California, San Francisco, San \\ Francisco, California 94143
}

Non-neurogenic cell types, such as cortical astroglia and fibroblasts, can be directly converted into neurons by the overexpression of defined transcription factors. Normally, the cellular phenotype of such differentiated cells is remarkably stable and resists direct cell transdifferentiation. Here we show that the Ink4a/Arf (also known as Cdkn2a) locus is a developmental barrier to direct neuronal transdifferentiation induced by transcription factor overexpression. With serial passage in vitro, wild-type postnatal cortical astroglia become progressively resistant to Dlx2-induced neuronal transdifferentiation. In contrast, the neurogenic competence of Ink4a/Arfdeficient astroglia is both greatly increased and does not diminish through serial cell culture passage. Electrophysiological analysis further demonstrates the neuronal identity of cells induced from Ink4a/Arf-null astroglia, and short hairpin RNA-mediated acute knockdown of p16Ink4a and p19Arf p16 ${ }^{\text {Ink4a }}$ and p19 Arf indicates that these gene products function postnatally as a barrier to cellular transdifferentiation. Finally, we found that mouse fibroblasts deficient for Ink4a/Arf also exhibit greatly enhanced transcription factorinduced neuronal induction. These data indicate that Ink4a/Arf is a potent barrier to direct neuronal transdifferentiation and further suggest that this locus functions normally in the progressive developmental restriction of postnatal astrocytes.

Key words: astroglia; induced neuron; Ink4a/Arf; transcription factor; transdifferentiation

\section{Introduction}

Neurons can be directly converted from non-neuronal cell types via the enforced expression of specific transcription factors (Vierbuchen and Wernig, 2012). Other than tissue-specific stem cell populations, cells in the adult mammal generally do not change their cellular identities, and this inherent phenotypic stability represents a barrier to cell transdifferentiation (Zhou and Melton, 2008). Thus, discovering the molecular-genetic mechanisms that facilitate direct neuronal transdifferentiation provides insight into how cell fates normally become restricted, and may also inform strategies that enhance cell fate conversion for the purpose of disease-modeling and cell-based therapeutics.

The Ink4a/Arf tumor suppressor locus encodes the p16 ${ }^{\text {Ink4a }}$ and $\mathrm{p} 19^{\text {Arf }}$ cell cycle inhibitors, which are expressed at basal levels in differentiated cell types. In addition to their function in tumor

Received July 24, 2013; revised Aug. 1, 2014; accepted Aug. 6, 2014.

Author contributions: J.D.P., K.-Y.P., and D.A.L. designed research; J.D.P., K.-Y.P., J.C., R.D.S., and M.J.C. performed research; J.D.P., K.Y.P., J.C., R.D.S., M.J.C., A.R.K., and D.A.L. analyzed data; J.D.P., K.-Y.P., and D.A.L. wrote the paper.

This work was supported by National Institutes of Health DP2-0D006505-01, the Sontag Foundation, a Northern California Institute for Research and Education/Department of Defense subaward to D.A.L., the Shurl and Kay Curci Foundation, and the San Francisco Veterans Affairs Medical Center for resources.

The authors declare no competing financial interests.

*J.D.P. and K.-Y.P. contributed equally to this work.

Correspondence should be addressed to Dr. Daniel A. Lim, University of California, San Francisco, 35 Medical Center Way, San Francisco, CA 94143. E-mail: Limd@neurosurg.ucsf.edu.

DOI:10.1523/JNEUROSCI.3159-13.2014

Copyright $\odot 2014$ the authors $\quad 0270-6474 / 14 / 3412560-08 \$ 15.00 / 0$ suppression (Kim and Sharpless, 2006), Ink4a/Arf gene products impede the generation of induced pluripotent stem cells (iPSCs) from fibroblasts: Ink4a/Arf is rapidly silenced during iPSC production, and Ink4a/Arf-deficient fibroblasts generate iPSCs more efficiently (Banito et al., 2009; Li et al., 2009; Utikal et al., 2009). Whether Ink4a/Arf also constitutes a barrier to direct neuronal reprogramming is not known.

During postnatal development, astrocytes in the mouse cerebral cortex divide symmetrically, greatly expanding their numbers (Ge et al., 2012); and when isolated from postnatal day 7 (P7) mice, astroglial cells still exhibit developmental plasticity: these young astroglia can give rise to multipotent neurospheres (Palmer et al., 1999; Laywell et al., 2000) and can also be converted into mature neurons via enforced expression of neurogenic transcription factors, such as Dlx2 (Heins et al., 2002; Berninger et al., 2007; Heinrich et al., 2010). However, cortical astrocytes from P15 mice no longer give rise to neurospheres (Laywell et al., 2000), and transcription factor-mediated neuronal transdifferentiation is greatly hindered in cells isolated from later postnatal mice (Heinrich et al., 2011; Robel et al., 2011). Thus, during this postnatal period of symmetric glial cell proliferation, cortical astrocytes appear to lose their neurogenic "competence."

Here, we used transcription factor-mediated neuronal transdifferentiation to gain insight into the molecular-genetic mechanisms that normally restrict neurogenic competence. We found that Ink4a/Arf is a potent barrier to direct neuronal transdiffer- 
entiation of mouse astroglia isolated from non-neurogenic brain regions as well as mouse fibroblasts. Our findings suggest a generalizable approach to enhance direct cell conversion methodologies and further indicate a role for Ink $4 a / A r f$ in the postnatal glial-fate restriction of parenchymal astrocytes.

\section{Materials and Methods}

Animals. Ink4a/Arf-null mice were maintained and genotyped as in Serrano et al. (1996). All experiments were performed with mice of either sex and in accordance to protocols approved by the Institutional Animal Care and Use Committee at University of California, San Francisco.

Cell culture and neuronal transdifferentiation. Postnatal cortical astroglial cultures were established essentially as in Berninger et al. (2007). Briefly, cortical tissue above the corpus callosum was microdissected from P5-P7 mouse brain sections, dissociated by treatment with $0.25 \%$ trypsin 0.5 mM EDTA as in Lim et al. (2009), and plated into 6-well culture plates (Corning) coated with $0.1 \mathrm{mg} / \mathrm{ml}$ poly-D-lysine (SigmaAldrich) in astrocyte growth medium described by Heinrich et al. (2010). Glial cultures were replated 5-7 d later into 16-well poly-D-lysine-coated Nunc Lab-Tek chamber slides (Thermo Scientific) at a density of 50,000 cells per well (passage 1) or passaged into culture plates for continued culture in astrocyte growth medium. Cells in chamber slides were infected with lentivirus and switched to astrocyte differentiation medium (DMEM/F12, B27, glutamine, and penicillin/streptomycin) (Heinrich et al., 2010) $24 \mathrm{~h}$ later.

Mouse embryonic fibroblasts (MEFs) were isolated and cultured in N3 medium (DMEM/F12, apotransferrin, insulin, sodium selenite, progesterone, putrescine, andpenicillin/streptomycin) (Vierbuchen et al., 2010). Passage 3 MEFs were transduced with lentivirus expressing reverse tetracycline transactivator (FUW-M2rtTA (Hockemeyer et al., 2008) and the transcription factors Myt1l and Brn2 (Vierbuchen et al., 2010), and rat Ascll expressed from the doxycycline-inducible lentiviral vector tetO-FUW. At $16-20 \mathrm{~h}$ after infection, cells were switched to fresh MEF medium containing doxycycline $(2 \mu \mathrm{g} / \mathrm{ml}$, Sigma). At $48 \mathrm{~h}$ after the addition of doxycycline, cells were switched to N3 medium containing doxycycline, which was replaced every $3 \mathrm{~d}$. Neuronal differentiation was analyzed by immunocytochemistry $20 \mathrm{~d}$ after infection.

Immunocytochemistry. Immunocytochemistry was performed as in Lim et al. (2009) with the following primary antibodies: mouse anti-Tuj1 (Covance), chicken anti-GFP (Aves), rabbit anti-dsRed (Clontech), rabbit anti-Nestin (Millipore), guinea pig anti-GLAST (Millipore), rabbit anti-S100 $\beta$ (Sigma), chicken anti-GFAP (Millipore), chicken anti-vimentin (Millipore), mouse anti-phospho-histone H3 (Millipore), rabbit anti-Pax6 (Covance), and rabbit anti-Sox2 (Santa Cruz Biotechnology). DAPI (Sigma) was used for nuclear staining.

Microscopy, cell counting, and statistical analysis. For quantification of cell cultures, at least 6 random, nonoverlapping fields of view were digitally acquired at 100-200× magnification (CMI 4000B, Leica), and cells were counted manually with aid of ImageJ (National Institutes of Health) or the Leica Application Suite Advanced Fluorescence software (Leica). Significance was calculated with Student's $t$ test using Excel (Microsoft).

Electrophysiology. Cells were analyzed 14-30 d after infection. The patch electrodes were made from borosilicate glass capillaries (Sutter Instruments) with a resistance in the range of 5-7 $\mathrm{M} \Omega$. The pipettes were tip-filled with internal solution containing the following (in $\mathrm{mM}$ ): 125 K-gluconate, $15 \mathrm{KCl}, 10$ HEPES, $4 \mathrm{MgCl}_{2}, 4 \mathrm{Na}_{2} \mathrm{ATP}, 0.3 \mathrm{Na}_{3} \mathrm{GTP}, 10$ Tris-phosphocreatine, 0.2 EGTA. The bath was constantly perfused with fresh recording medium containing the following (in $\mathrm{mm}$ ): $145 \mathrm{NaCl}, 3$ $\mathrm{KCl}, 3 \mathrm{CaCl}_{2}, 2 \mathrm{MgCl}_{2}, 10 \mathrm{HEPES}, 8$ glucose, at room temperature. Recordings were made with an Axon 700B patch-clamp amplifier and $1320 \mathrm{~A}$ interface (Molecular Devices). Signals were filtered at $2 \mathrm{kHz}$ using amplifier circuitry, sampled at $10 \mathrm{kHz}$, and analyzed using Clampex 10.2 (Molecular Devices).

Microarray and qRT-PCR analysis. Analysis by qPCR was performed as in Ramos et al. (2013). For microarray analysis, samples from three replicate cultures for each cell type were prepared as in Ramos et al. (2013) and hybridized to MouseRef-8 v2.0 Expression BeadChip arrays (Illumina). Array data were processed and analyzed as in Park et al. (2014).
Lentiviral production. To acutely knock-down Ink4a/Arf, one short hairpin RNA (shRNA) sequence against Ink4a/Arf (targeting sequence: AATGGCTGGATTGTTTAAA) (Fasano et al., 2007) and one control sequence targeting luciferase described in targeting sequence: GAGCTGTTTCTGAGGAGCC (Ventura et al., 2004) was cloned into the lentiviral vector $\mathrm{pSicoR}-\mathrm{mCh}$ (a gift from Dr. Miguel Ramalho-Santos). The efficiency of viral transduction ranged from 95 to $98 \%$, and no significant differences were observed between wild-type (WT) and null glia. Brn2, Ascll, and Myt1l lentiviral vectors have been described previously (Vierbuchen et al., 2010) and were obtained through Addgene. VSV-G and EnvA pseudotyped lentiviruses were produced in HEK 293T cells as in Lewis et al. (2001).

\section{Results}

\section{Loss of neurogenic competence of cortical astroglia through serial passage in vitro}

P5-P7 cortical astroglial cultures infected with lentivirus expressing $D l \times 2$ and the GFP marker (LV-Dlx2-GFP) but not GFP alone (LV-GFP) produced GFP-positive neuronal cells immunopositive for $\beta$ III Tubulin (Tuj1-positive) after $7 \mathrm{~d}$ of differentiation (Fig. 1 $A, B$ ). We investigated whether this "neurogenic competence" is maintained through serial passage in vitro. Cortical astroglia were serially passaged 5 times over $15 \mathrm{~d}$, infected with LV-Dlx2-GFP or LV-GFP at passages 1, 2, 3, and 5, and neuronal differentiation was quantified $8 \mathrm{~d}$ after infection. While the efficiency of LV-Dlx2-GFP induced neuronal transdifferentiation was $\sim 7 \%$ at passage 1 (Fig. $1 B$, Pass 1 ), the percentage of Tuj1positive LV-Dlx2-GFP transduced cells was reduced 2.7-fold by passage 2 (Fig. $1 B$, Pass 2), becoming 8.5 -fold reduced $(0.8 \%$ efficiency) at passage 5 (Fig. $1 B$, Pass 5 ). Thus, with serial in vitro passage, cortical astroglia derived from P5-P7 mice progressively lose their neurogenic competence.

\section{Ink4a/Arf deficiency enhances the neurogenic competence of postnatal astroglia}

Ink4a/Arf is expressed in cortical astroglial cultures but not neurogenic neural precursors (Bachoo et al., 2002). To determine whether Ink4a/Arf is a barrier to neuronal transdifferentiation, we produced cultures from Ink4a/Arf-null mice and WT littermates. Interestingly, at passage 1, Ink4a/Arf-null astroglia exhibited low levels of neurogenesis even without enforced expression of Dlx2 (Fig. 1B), possibly because of low levels of neural stem cell-like behavior in response to EGF signaling, as previously reported (Bachoo et al., 2002). However, by passage 3, very little of this neural stem cell-like behavior remained (Fig. $1 B$ ). In contrast, at passage $1, \mathrm{LV}-\mathrm{Dl} \times 2$-GFP induced neuronal differentiation in $25.17 \%$ ( $\mathrm{SD}=1.14 \%, n=4$ independent experiments) of infected Ink4a/Arf-null cells (Fig. $1 B$, Pass 1), resulting in $\sim 4$-fold more neurons than in WT cultures. Furthermore, the neurogenic competence of Ink4a/Arf-null cells did not diminish with continued in vitro passage (Fig. $1 B$, Pass $1-5$ ); by passage 5, transdifferentiation of Ink4a/Arf-null astroglial cells was $\sim 30$-fold more efficient than WT cells (Fig. 1B). Thus, Ink4a/Arf deficiency both enhances and maintains the neurogenic competence of postnatal cortical astroglia.

In typical neural cell growth media, Ink4a/Arf-null astroglia grow faster than WT cultures, and cellular reprogramming, such as that of iPSCs, can be promoted by high rates of proliferation (Hanna et al., 2009). To address the possibility that the increased proliferation rate of Ink4a/Arf-null astroglia relates to their enhanced transdifferentiation potential, we reduced the rate of cell proliferation by omitting recombinant EGF and bFGF from the growth medium. Ink4a/Arf-null astroglia grown without exogenous EGF and bFGF incorporated the thymidine analog ethynyl 
A

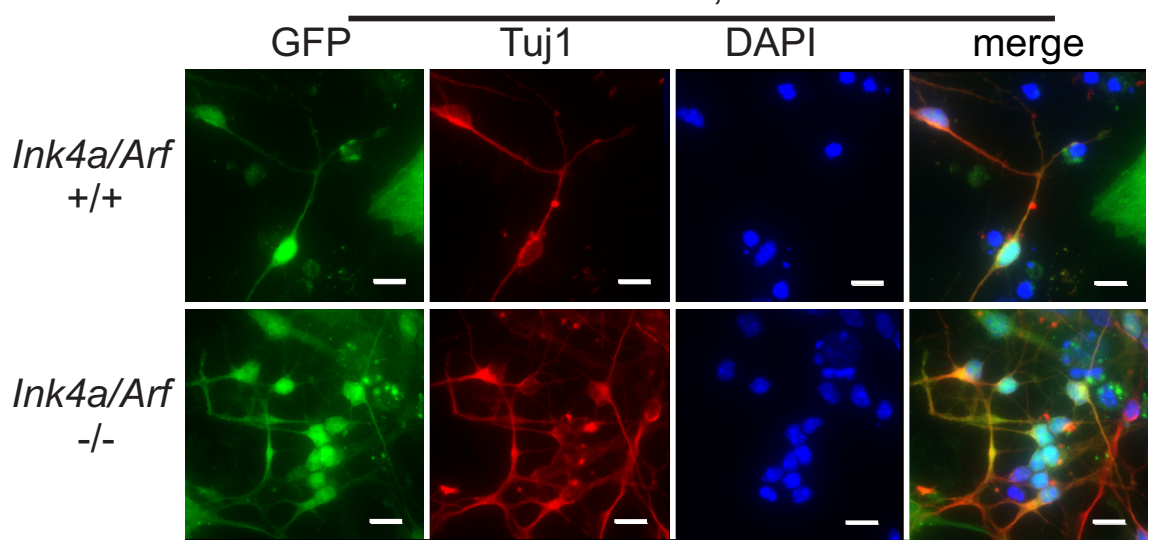

B

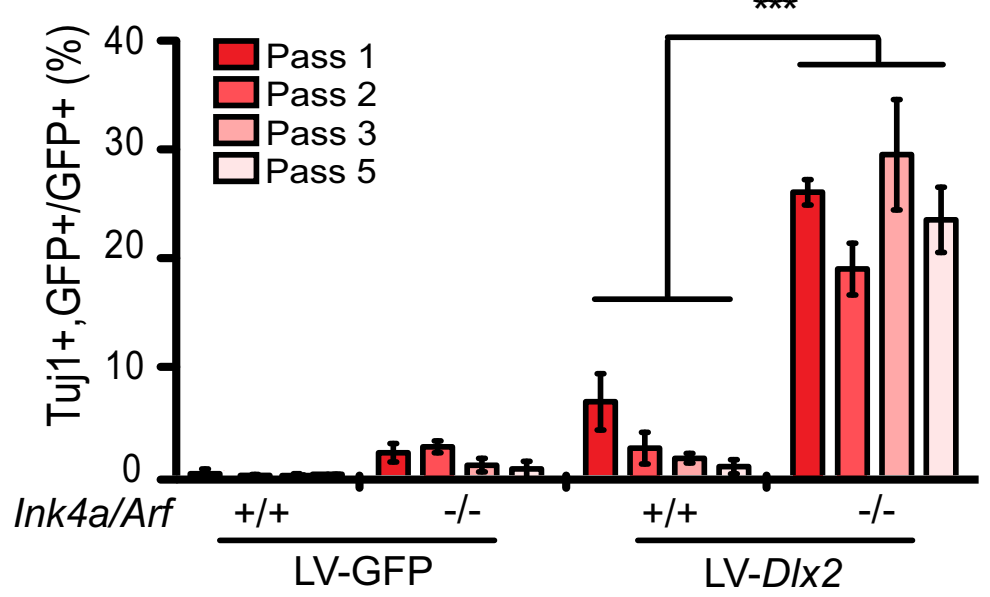

C

D
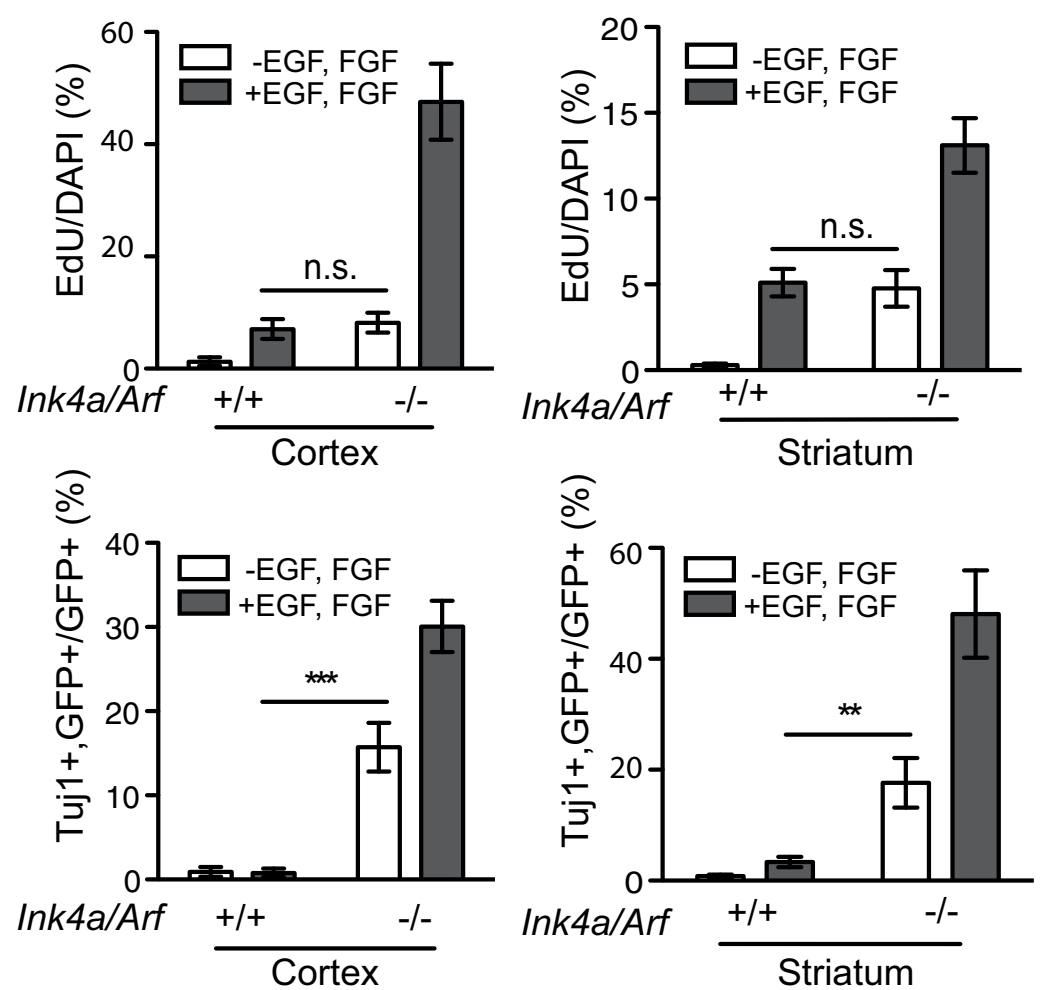

Figure 1. Ink4a/Arf deficiency enhances neuronal transdifferentiation. $\boldsymbol{A}$, Immunocytochemistry for GFP (green) and Tuj1 (red) of Ink4a/Arf-null and WT astroglia infected at passage 1 (Pass 1) with LV-DIX2-GFP. B, Transdifferentiation efficiencies of astroglia deoxyuridine (EdU) at a rate similar to WT astroglia cultured with EGF and bFGF (Fig. 1C); despite a nearly sixfold reduction in EdU incorporation, Inka/ Arf-null astroglia cultured in growth factor-deficient conditions still exhibited 20 -fold greater LV-Dlx2-GFP-induced neuronal transdifferentiation, compared with WT astroglia grown with EGF and bFGF (Fig. 1D). Thus, independent of the rate of cell proliferation, Ink4a/Arf deficiency promotes neuronal transdifferentiation in cortical astroglia.

Because parenchymal astrocytes can be regionally distinct (Zhang and Barres, 2010), we next asked whether Ink4a/Arfnull astroglia from other non-neurogenic brain regions also exhibit increased efficiencies of neuronal transdifferentiation. Whereas astroglia derived from the cerebellum and brainstem did not grow well under these culture conditions and therefore could not be evaluated, striatal astroglia did propagate efficiently. LV-Dlx2-GFP induced neuronal differentiation of astroglial cells in Ink4a/Arf-null striatal cultures with $>5$-fold greater efficiency than WT controls (Fig. 1D), even when cultured in media without EGF and bFGF, indicating that Ink4a/Arfdeficiency enhances neuronal transdifferentiation in regionally distinct populations of astroglia.

GFAP-positive, Ink4a/Arf-null astroglia exhibit increased neurogenic

competence

Although astroglial cultures from both Ink4a/Arf-null and WT cortex contained similar proportions of cells expressing Nestin, GLAST, OLIG2, and NG2 (Fig. 2A), Ink4a/Arf-null cultures contained $\sim 20 \%$ fewer cells expressing GFAP, a marker of astrocyte identity. We therefore investigated whether Ink4a/Arf deficiency in GFAP-positive astroglia enhances neuronal transdifferentiation.

We restricted LV-Dlx2-GFP infection to cells expressing GFAP. EnvA pseudotyped lentiviruses (LV/EnvA) cannot infect mammalian cells unless they express the avian viral receptor gene, tv-a (Lewis et al., 2001). The Gtv-a mouse transgene expresses tv-a from the GFAP promoter, enabling LV/EnvA infection of

$\leftarrow$

serially cultured from passage 1 (bright red) through 5 (light pink). C, Quantification of EdU-positive cells in Ink4a/Arf-null and WT cortical (left) and striatal (right) astroglial cultures, with and without exogenous EGF and FGF. D, Efficiencies of neuronal conversion of cells from $C$ with and without exogenous EGF and FGF. Error bars indicate SEM. ${ }^{* *} p<0.01$. ${ }^{* * *} p<0.001$. n.s., Not significant. Scale bars, $10 \mu \mathrm{m}$. 
A
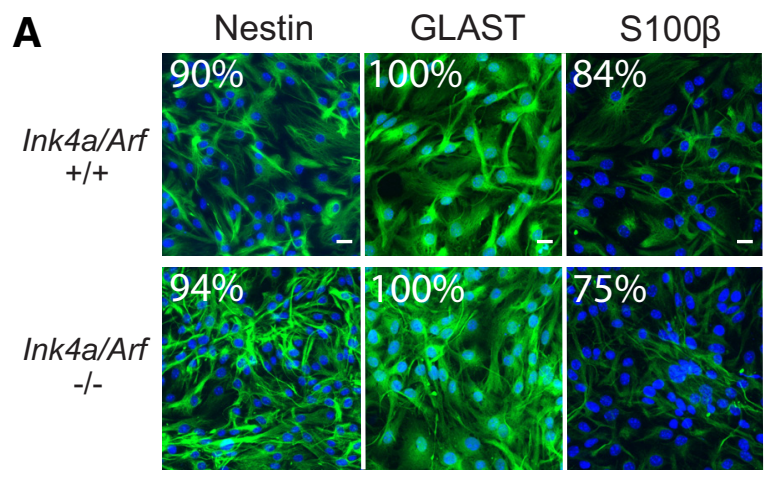
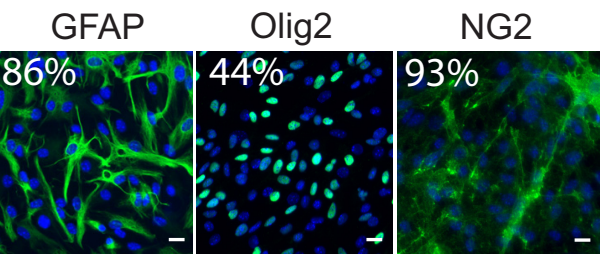

B

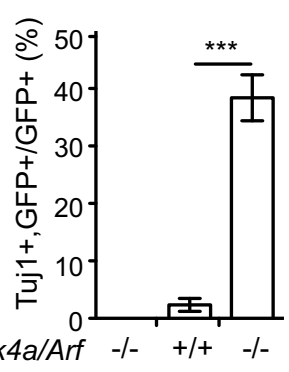

C Ink4a/Arf-null, LV-D/x2, 2-3 weeks differentiation
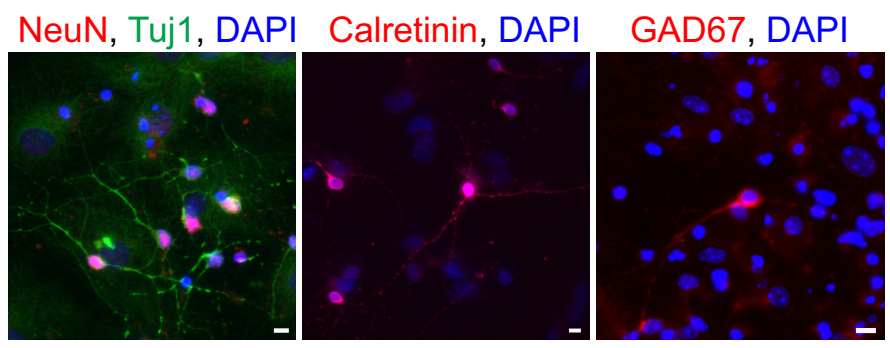

$\begin{array}{rrr}\text { LV-EnvA-GFP } & + & - \\ - & +\end{array}$

D

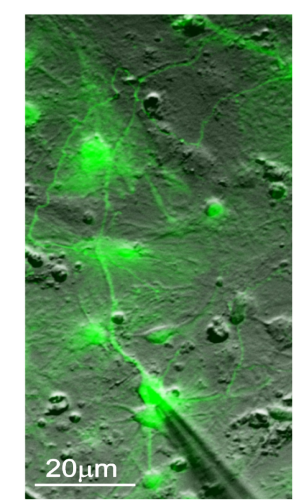

E
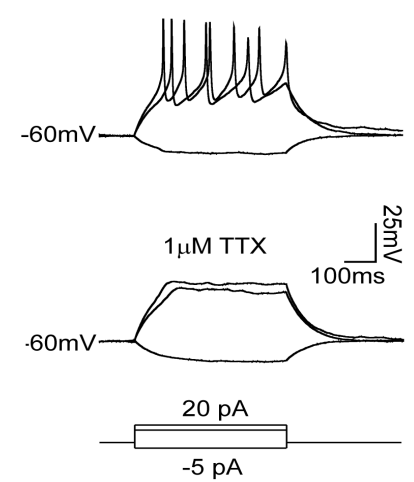

$\mathbf{F}$
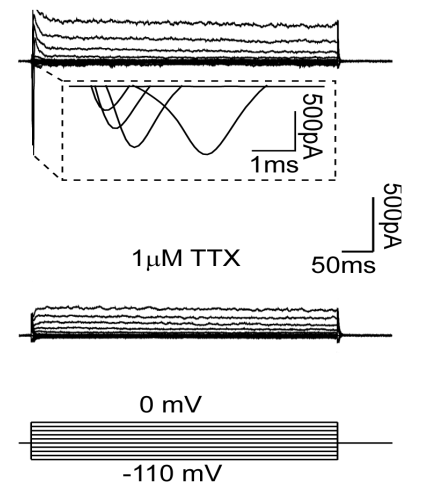

G

\begin{tabular}{|c|c|c|c|c|}
\hline & Spikelet & Few Spikes & Repetitive & Total Cell \\
\hline $\begin{array}{c}\text { Ink4a/Arf -/- } \\
\text { Dlx2 + Mash1 }\end{array}$ & 9 & 3 & 5 & 17 \\
\hline $\begin{array}{l}\text { Ink4a/Arf -/- } \\
\text { DIx2 }\end{array}$ & 35 & 11 & 2 & 48 \\
\hline $\begin{array}{c}\text { Ink4a/Arf +/+ } \\
\text { DIx2 }\end{array}$ & 10 & 3 & 1 & 14 \\
\hline
\end{tabular}

Figure 2. Transdifferentiated neuronal cells display markers of inhibitory interneuron fate and become electrophysiologically active. A, Immunocytochemistry for Nestin, GLAST, S100 $\beta, 0$ lig2, NG2, and GFAP (green) counterstained with DAPI (blue) of passage 1 cortical astroglia. Percentage of cells immunopositive for each marker is indicated (from 8 fields of view, 20X). Scale bars, 20 $\mu \mathrm{m} . \boldsymbol{B}$, Transdifferentiation efficiencies of Ink4a/Arf-null and WT astroglia transduced with Env-A-pseudotyped virus expressing GFP alone or D/x2-GFP. ${ }^{* * *} p<0.001$. C, Immunocytochemistry for NeuN, calretinin, and GAD67 (red), Tuj1 (green), and DAPI (blue). Scale bars, $10 \mu \mathrm{m}$. D, Merged differential interference contrast and fluorescence image showing an example of a recorded neuron. $\boldsymbol{E}$, Representative traces of $I n k 4 a / A r f^{-1-}$ neuron exhibiting repetitive action potentials (top) under stepped current injection (bottom) in current clamp. $\boldsymbol{F}$, Large inward $\mathrm{Na}{ }^{+}$currents under stepped voltage (bottom) in voltage clamp (top). Both $\mathrm{Na}^{+}$currents and action potentials were fully abolished upon application of $\mathrm{Na}^{+}$channel blocker $1 \mu \mathrm{M}$ TTX. G, Summary of action potentials recorded from Ink4a/Arf-null and WT neurons derived by infection with D/x2 + Mash1 or D/x2 alone. 
A

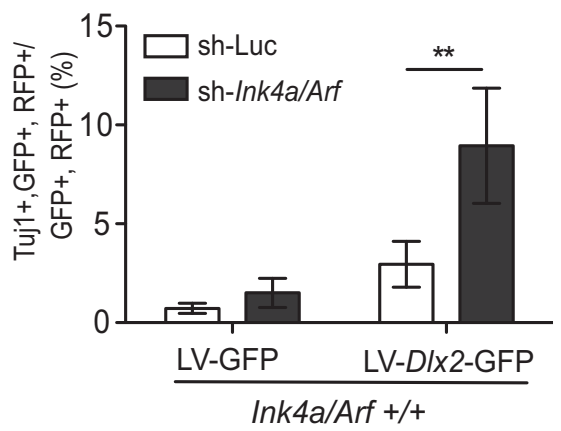

C

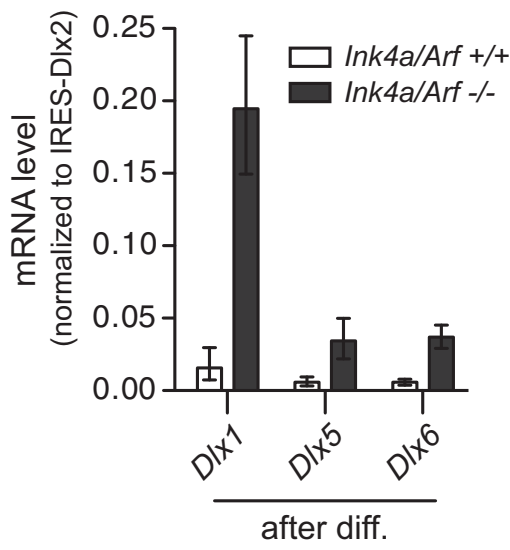

B

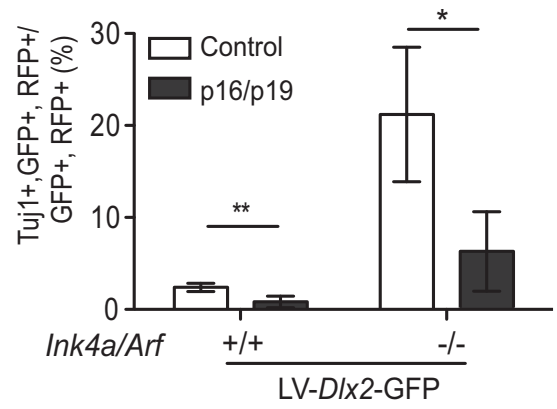

D

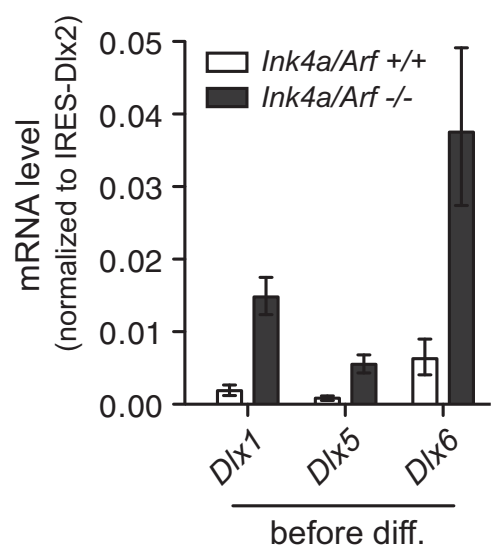

E

\begin{tabular}{|c|c|c|c|c|}
\hline Gene ID & Gene Symbol & Description & Fold Change in Null & p-Value \\
\hline 11834 & AQR & aquarius intron-binding spliceosomal factor & 2.2723 & 1.495E-05 \\
\hline 100042493 & CCL21A & chemokine ( $\mathrm{C}-\mathrm{C}$ motif) ligand 21 & 2.1578 & 2.998E-04 \\
\hline 11537 & CFD & complement factor D (adipsin) & 2.2943 & 2.489E-02 \\
\hline 67529 & FGFR1OP2 & FGFR1 oncogene partner 2 & 2.1752 & 2.138E-05 \\
\hline 66606 & LRRC57 & leucine rich repeat containing 57 & 2.7283 & 1.314E-05 \\
\hline 67809 & RMDN3 & regulator of microtubule dynamics 3 & 2.0634 & 2.233E-06 \\
\hline 100213 & RUSC2 & $\mathrm{RUN}$ and $\mathrm{SH} 3$ domain containing 2 & 2.2669 & 6.806E-06 \\
\hline 16651 & SSPN & sarcospan & 2.1520 & $2.529 \mathrm{E}-04$ \\
\hline 21754 & TESK1 & testis specific protein kinase 1 & 2.6011 & 1.409E-05 \\
\hline 12331 & CAP1 & CAP, adenylate cyclase-associated protein 1 & -2.2045 & 1.916E-07 \\
\hline 12450 & CCNG1 & cyclin G1 & -2.4338 & $5.856 \mathrm{E}-05$ \\
\hline 12505 & CD44 & CD44 antigen & -2.1051 & 2.220E-08 \\
\hline 12575 & CDKN1A & cyclin-dependent kinase inhibitor $1 \mathrm{~A}$ & -4.4689 & $1.762 E-05$ \\
\hline 12578 & CDKN2A & cyclin-dependent kinase inhibitor $2 \mathrm{~A}$ & -3.4479 & 6.798E-12 \\
\hline 333182 & COX6B2 & cytochrome c oxidase subunit VIb polypeptide 2 & -2.4131 & 3.499E-05 \\
\hline 67880 & DCXR & dicarbonyl/L-xylulose reductase & -2.5716 & 2.829E-05 \\
\hline 13849 & EPHX1 & epoxide hydrolase 1 , microsomal & -2.4240 & 2.762E-07 \\
\hline 14456 & GAS6 & growth arrest specific 6 & -2.0353 & 1.079E-04 \\
\hline 93695 & GPNMB & glycoprotein (transmembrane) nmb & -2.0055 & 5.207E-05 \\
\hline 29870 & GTSE1 & G-2 and S-phase expressed 1 & -2.2249 & 2.334E-04 \\
\hline 27280 & PHLDA3 & pleckstrin homology-like domain, family A, member 3 & -3.6802 & 2.108E-06 \\
\hline 217430 & PQLC3 & PQ loop repeat containing 3 & -2.7262 & 4.491E-05 \\
\hline 20280 & SCP2 & sterol carrier protein 2 & -2.0279 & $6.908 \mathrm{E}-10$ \\
\hline 116914 & SLC19A2 & solute carrier family 19 (thiamine transporter), member 2 & -2.0600 & 4.861E-05 \\
\hline 68666 & SVOP & SV2 related protein homolog & -3.4871 & 2.069E-04 \\
\hline 211499 & TMEM87A & transmembrane protein $87 \mathrm{~A}$ & -2.2476 & 2.366E-05 \\
\hline
\end{tabular}

Figure 3. Acute changes to Ink4a/Arf affect transdifferentiation efficiency. $\boldsymbol{A}$, Trandifferentiation efficiencies of Ink4a/Arf WT astroglia infected with lentivirus expressing RFP and an shRNA targeting Ink4a/Arf or control. Luc, Luciferase. B, Transdifferentiation efficiencies of Ink4a/Arf WT or null glia infected with virus overexpressing RFP both $p 16^{\text {Ink } 4 a}$ and $p 19^{A r f}$ or control (alkaline phosphatase). C, qRT-PCR expression analysis of D/x1,D/x5, and D/x6 expression after LV-D/x2-GFP infection after differentiation. D, qRT-PCR expression analysis of D/x1, D/x5, and D/x6 expression after LV-DIX2-GFP infection before differentiation. ${ }^{*} p<0.05$. ${ }^{* *} p<0.01$. Error bars indicate SD of triplicate reactions. $\boldsymbol{E}$, Summary of microarray expression data for genes calculated to be greater than twofold different between Ink4a/Arf WT or null glial cultures. 
A

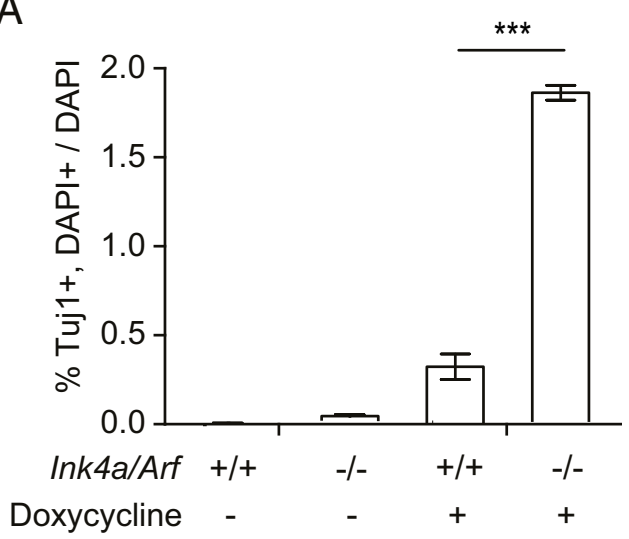

B

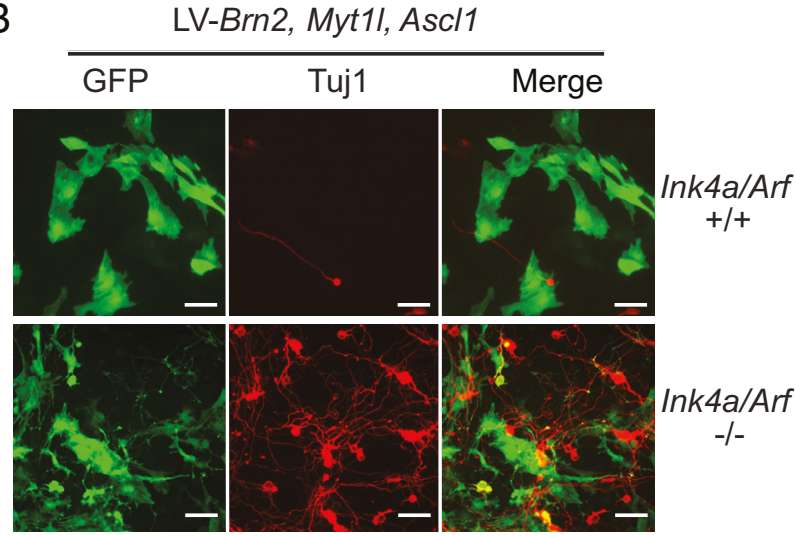

Figure 4. Ink4a/Arf is a barrier to fibroblast neuronal reprogramming. $A$, Transdifferentiation efficiencies from Ink4a/Arf-null and WT MEFs infected with lentivirus expressing Brn2, Myt 11 , and Ascl1 with or without induction by doxycycline. $\boldsymbol{B}$, Immunocytochemistry for Tuj1 and GFP from MEF cultures $7 \mathrm{~d}$ after infection $(\boldsymbol{B}){ }^{* * *} p<0.001$. Scale bars, $40 \mu \mathrm{m}$.

GFAP-positive astroglia (Holland et al., 1998). When infected with LV/EnvA-Dlx2-GFP, Gtv-a;Ink4a/Arf-null astroglial cultures exhibited $>10$-fold higher neuronal differentiation efficiency compared with Gtv-a;Ink4a/Arf ${ }^{+/+}$control cultures (Fig. $2 B)$. When infected with the LV/EnvA-GFP control virus, Gtv-a; Ink4a/Arf-null cells did not give rise to neurons, indicating that the low levels of neurogenesis observed in Ink4a/Arf-null cortical cultures without enforced $D l x 2$ expression (Fig. $1 B$ ) likely originated from a GFAP-negative cell population. Together, these data indicate that Ink4a/Arf deficiency facilitates neuronal transdifferentiation from GFAP-positive astroglia.

\section{Neurons induced from Ink4a/Arf-deficient cells fire action potentials}

Neuronal cells induced from Ink4a/Arf-null cells by LV-Dlx2GFP were immunopositive for neuronal antigen NeuN (399 of 857 Tuj $1^{+}$cells; $46.6 \%$ ) as well as calretinin (40 of 169 Tuj ${ }^{+}$ cells; 23.7\%) and GAD67 (45 of 169 Tuj1 ${ }^{+}$cells; 26.6\%) (Fig. $2 C)$. To further characterize their neuronal identity, we used electrophysiological analysis (Fig. 2D-G). As in WT astroglia, Dlx2 alone was sufficient to generate neurons in Ink4a/Arfnull cultures that were able to fire action potentials; however, after 2-3 weeks of differentiation, a large proportion of transdifferentiated cells exhibited immature action potential firing patterns (few spikes, Fig. 2E). In WT postnatal astroglia, coexpression of proneural Mash1 (Ascl1) with Dlx2 promotes further neuronal maturation (Heinrich et al., 2010). We therefore coexpressed Mash 1 and Dlx2 from lentiviral vectors in Ink4a/Arf-null cells and found that GFP-positive neuronal cells exhibited repetitive action potential firing patterns under current clamp, as well as large inward $\mathrm{Na}^{+}$currents under voltage clamp, and both were sensitive to the $\mathrm{Na}^{+}$channel blocker TTX (Fig. 2E,F). Indeed, Ink4a/Arf-null astroglial cultures transduced with both Mash1 and Dlx2 lentiviral vectors produced a greater proportion of neuronal cells with repetitive spiking than Dlx2 alone (Fig. 2G).

\section{Acute changes to Ink4a/Arf expression regulate neurogenic competence}

We next investigated whether acute inhibition of Ink4a/Arf expression can increase astroglial neurogenic competence. Lentiviruses encoding shRNAs targeting both Ink $4 a$ and Arf (LV-sh-Ink4a/Arf-mCherry) reduced their transcript levels in passage 1 cortical astroglial cells by $>80 \%$ after $2 \mathrm{~d}$ relative to control LV-sh-luciferase-mCherry; these cultures were next infected with LV-Dlx2-GFP or LV-GFP, and the cellular phenotype of double-infected cells (mCherry/GFP-positive) was quantified after differentiation. Cells transduced with LV-shInk4a/Arf-mCherry exhibited $\sim 3$-fold greater neuronal differentiation compared with LV-sh-luciferase-mCherry control (Fig. 3A).

To determine whether enforced expression of Ink4a and Arf would conversely inhibit neuronal transdifferentiation in Ink4al Arf-null astroglia, we infected Ink4a/Arf-null and WT passage 1 cortical astroglial cultures with lentivirus encoding p16 ${ }^{\text {Ink4a }}$ and p19 ${ }^{\text {Arf }}$ cDNAs (LV-Ink4a-P2A-Arf-mCherry) or LV-mCherry control vectors and assessed the efficiency of neuronal transdifferentiation induced by LV-Dlx2-GFP. Reexpression of Ink4a/Arf reduced the number of Tuj1-positive neuronal cells by $\sim 2.5$-fold in both Ink4a/Arf-null and WT cells (Fig. 3B). Thus, acute changes to $I n k 4 a$ and $A r f$ transcript levels can rapidly alter the neurogenic competence of astroglia.

\section{Ink4a/Arf-null glia cultures more efficiently activate Dlx2-dependent transcription}

To begin to investigate why Ink4a/Arf deficiency enhances the neurogenic competence of postnatal astroglia, we compared the Ink4a/Arf-null transcriptome to that of WT controls. Surprisingly, in Ink4a/Arf-null cultures, only 27 genes were differentially expressed by $>2$-fold (Fig. $3 E$ ).

In normal development, DLX2 upregulates expression of both the $D l \times 1 / 2$ and $D l \times 5 / 6$ bigene clusters, which are key regulators of interneuron development (Panganiban and Rubenstein, 2002). To determine whether $D l \times 2$ overexpression can activate the transcription of these DLX2 target genes, we analyzed gene expression during LV-Dlx2-GFP-induced neuronal transdifferentiation. Three days after differentiation with LV-Dlx2-GFP, Ink4a/Arfnull cultures exhibited $>10$-fold higher levels of $D l x 1, D l \times 5$, and Dlx6 (Fig. 3C). To analyze gene expression related to the enforced expression of $D l \times 2$ rather than the resultant neuronal differentiation, we analyzed cultures before the onset of neurogenesis. Even before the emergence of Tuj1-positive cells, LV-Dlx2-GFP induced nearly sixfold higher levels of $D l x 1$ and $D l \times 5 / 6$ expression in Ink4a/Arf-null cultures (Fig. 3D). Thus, Ink4a/Arfdeficient astroglia are more competent to upregulate DLX2 downstream targets. 


\section{Ink4a/Arf is a barrier to direct neuronal reprogramming of fibroblasts}

To further explore whether the Ink4a/Arf locus is a barrier to direct neuronal transdifferentiation, we investigated direct neuronal transdifferentiation of non-neural cells. MEFs can be converted into neurons via overexpression of the transcription factors Brn2, Ascl1, and Myt1l (Vierbuchen et al., 2010). We infected MEFs from Ink4a/Arf-null and WT littermates with lentiviruses expressing the reverse tetracycline transactivator, and a pool of lentiviruses expressing Brn2, Ascl1, and Myt1l under the control of the tetracycline response element. As expected, $19 \mathrm{~d}$ after transcription factor induction with doxycycline, we observed Tuj1-positive cells with neuronal morphologies in WT MEF cultures; from Ink4a/Arf-null MEF cultures, neuronal transdifferentiation was nearly sixfold greater (Fig. 4A,B). Thus, Ink $4 a / A r f$ is a barrier to neuronal transdifferentiation in both neural and non-neural cell types.

\section{Discussion}

A major challenge to the direct conversion of one mature cell type into another is that the identity of differentiated cells is generally very stable and difficult to alter (Zhou and Melton, 2008; Vierbuchen and Wernig, 2012). How cells achieve and maintain such stable, mature phenotypes is poorly understood. We show that Ink4a/Arf-deficient cells exhibit greatly increased competence for direct neuronal transdifferentiation. In addition to enabling greater efficiencies of neuronal conversion for the advancement of cell reprogramming technologies, our findings suggest that Ink $4 a / A r f$ is a genetic requirement for the proper stabilization of mature astrocyte identity.

Astrocytes arise from radial glia, the primary multipotent embryonic neural stem cell population (Kriegstein and AlvarezBuylla, 2009). In the postnatal mouse cortex, astrocytes proliferate through symmetric division (Ge et al., 2012). As others (Palmer et al., 1999; Laywell et al., 2000; Heins et al., 2002; Berninger et al., 2007; Heinrich et al., 2010) and we have shown here, early postnatal cortical astroglia still exhibit developmental plasticity. However, astroglia isolated from later postnatal ages have greatly diminished neurogenic competence (Laywell et al., 2000; Heinrich et al., 2011). Interestingly, cortical astroglia became increasingly resistant to neuronal conversion through serial passage, suggesting that this lineage restriction is progressive in nature and related to their proliferation. In contrast, the neurogenic competence of Ink4a/Arf-null astroglia did not diminish with serial passage, indicating that Ink4a/Arf is required for the observed restriction to astrocyte identity.

Using Dlx2, one of the major transcription factors that controls inhibitory interneuron fate, we were able to generate neurons that display markers of an inhibitory interneuron identity. It is feasible that the use of other lineage-specific transcription factors alone or in combination may yield other neuronal subtypes. Additionally, astroglial heterogeneity related to location or embryonic origin may play a role in the responsiveness to these factors, as transdifferentiation efficiency of striatal astrocytes appeared to be $\sim 60 \%$ higher than those derived from the cortex.

Ink4a/Arf-null astrocytes are immortal (Bachoo et al., 2002), and this nonsenescent proliferation may also relate to their persistent neurogenic competence. Ink4a/Arf is a key mediator of senescence (Collado et al., 2007), and Ink4a/Arf as well as other senescence mediators are barriers to iPSC production (Banito et al., 2009; Li et al., 2009; Utikal et al., 2009). Reintroduction of p16 ${ }^{\text {Ink4a }}$ and $19^{\text {Arf }}$ transcripts into Ink4a/Arf-null cells restores replicative senescence; and, indeed, astroglial neurogenic compe- tence was inhibited by lentiviral expression of Ink4a/Arf transcripts. Although WT cortical astroglia became refractory to proliferation after Passage 5, we did not observe any classical markers of senescence (e.g., $\beta$-galactosidase activity, heterochromatin foci) in WT astrocyte cultures before this point (data not shown). Thus, we suggest that proliferation toward Ink4a/Arfdependent senescence limits the neurogenic competence of astroglia. Interestingly, astroglia in the adult subventricular zone repress Ink4a/Arf via Polycomb-dependent mechanisms (Molofsky et al., 2003), and these subventricular zone astrocytes maintain neurogenic competence, generating large numbers of neurons throughout life (Kriegstein and Alvarez-Buylla, 2009).

Overall, our results indicate that inactivation of Ink4a/Arf greatly improves transcription factor-mediated neuronal transdifferentiation. This finding not only has important implications for the advancement of direct cell conversion methodologies, our data also implicate Ink4a/Arf as a key genetic locus in the normal developmental lineage-restriction of astroglial cells in nonneurogenic brain regions.

\section{References}

Bachoo RM, Maher EA, Ligon KL, Sharpless NE, Chan SS, You MJ, Tang Y, DeFrances J, Stover E, Weissleder R, Rowitch DH, Louis DN, DePinho RA (2002) Epidermal growth factor receptor and Ink4a/Arf: convergent mechanisms governing terminal differentiation and transformation along the neural stem cell to astrocyte axis. Cancer Cell 1:269-277. CrossRef Medline

Banito A, Rashid ST, Acosta JC, Li S, Pereira CF, Geti I, Pinho S, Silva JC, Azuara V, Walsh M, Vallier L, Gil J (2009) Senescence impairs successful reprogramming to pluripotent stem cells. Genes Dev 23:2134-2139. CrossRef Medline

Berninger B, Costa MR, Koch U, Schroeder T, Sutor B, Grothe B, Götz M (2007) Functional properties of neurons derived from in vitro reprogrammed postnatal astroglia. J Neurosci 27:8654-8664. CrossRef Medline

Collado M, Blasco MA, Serrano M (2007) Cellular senescence in cancer and aging. Cell 130:223-233. CrossRef Medline

Fasano CA, Dimos JT, Ivanova NB, Lowry N, Lemischka IR, Temple S (2007) shRNA knockdown of Bmi-1 reveals a critical role for $\mathrm{p} 21-\mathrm{Rb}$ pathway in NSC self-renewal during development. Cell Stem Cell 1:87-99. CrossRef Medline

Ge WP, Miyawaki A, Gage FH, Jan YN, Jan LY (2012) Local generation of glia is a major astrocyte source in postnatal cortex. Nature 484:376-380. CrossRef Medline

Hanna J, Saha K, Pando B, van Zon J, Lengner CJ, Creyghton MP, van Oudenaarden A, Jaenisch R (2009) Direct cell reprogramming is a stochastic process amenable to acceleration. Nature 462:595-601. CrossRef Medline

Heinrich C, Blum R, Gascón S, Masserdotti G, Tripathi P, Sánchez R, Tiedt S, Schroeder T, Götz M, Berninger B (2010) Directing astroglia from the cerebral cortex into subtype specific functional neurons. PLoS Biol 8:e1000373. CrossRef Medline

Heinrich C, Gascón S, Masserdotti G, Lepier A, Sanchez R, Simon-Ebert T, Schroeder T, Götz M, Berninger B (2011) Generation of subtypespecific neurons from postnatal astroglia of the mouse cerebral cortex. Nat Protoc 6:214-228. CrossRef Medline

Heins N, Malatesta P, Cecconi F, Nakafuku M, Tucker KL, Hack MA, Chapouton P, Barde YA, Götz M (2002) Glial cells generate neurons: the role of the transcription factor Pax6. Nat Neurosci 5:308-315. CrossRef Medline

Hockemeyer D, Soldner F, Cook EG, Gao Q, Mitalipova M, Jaenisch R (2008) A drug-inducible system for direct reprogramming of human somatic cells to pluripotency. Cell Stem Cell 3:346-353. CrossRef Medline

Holland EC, Hively WP, DePinho RA, Varmus HE (1998) A constitutively active epidermal growth factor receptor cooperates with disruption of G1 cell-cycle arrest pathways to induce glioma-like lesions in mice. Genes Dev 12:3675-3685. CrossRef Medline

Kim WY, Sharpless NE (2006) The regulation of INK4/ARF in cancer and aging. Cell 127:265-275. CrossRef Medline 
Kriegstein A, Alvarez-Buylla A (2009) The glial nature of embryonic and adult neural stem cells. Annu Rev Neurosci 32:149-184. CrossRef Medline

Laywell ED, Rakic P, Kukekov VG, Holland EC, Steindler DA (2000) Identification of a multipotent astrocytic stem cell in the immature and adult mouse brain. Proc Natl Acad Sci U S A 97:13883-13888. CrossRef Medline

Lewis BC, Chinnasamy N, Morgan RA, Varmus HE (2001) Development of an avian leukosis-sarcoma virus subgroup A pseudotyped lentiviral vector. J Virol 75:9339-9344. CrossRef Medline

Li H, Collado M, Villasante A, Strati K, Ortega S, Cañamero M, Blasco MA, Serrano M (2009) The Ink4/Arf locus is a barrier for iPS cell reprogramming. Nature 460:1136-1139. CrossRef Medline

Lim DA, Huang YC, Swigut T, Mirick AL, Garcia-Verdugo JM, Wysocka J, Ernst P, Alvarez-Buylla A (2009) Chromatin remodelling factor Mll1 is essential for neurogenesis from postnatal neural stem cells. Nature 458: 529-533. CrossRef Medline

Molofsky AV, Pardal R, Iwashita T, Park IK, Clarke MF, Morrison SJ (2003) Bmi-1 dependence distinguishes neural stem cell self-renewal from progenitor proliferation. Nature 425:962-967. CrossRef Medline

Palmer TD, Markakis EA, Willhoite AR, Safar F, Gage FH (1999) Fibroblast growth factor-2 activates a latent neurogenic program in neural stem cells from diverse regions of the adult CNS. J Neurosci 19:84878497. Medline

Panganiban G, Rubenstein JL (2002) Developmental functions of the Distal-less/Dlx homeobox genes. Development 129:4371-4386. Medline

Park DH, Hong SJ, Salinas RD, Liu SJ, Sun SW, Sgualdino J, Testa G, Matzuk MM, Iwamori N, Lim DA (2014) Activation of neuronal gene expres- sion by the JMJD3 demethylase is required for postnatal and adult brain neurogenesis. Cell Rep. In press. CrossRef

Ramos AD, Diaz A, Nellore A, Delgado RN, Park KY, Gonzales-Roybal G, Oldham MC, Song JS, Lim DA (2013) Integration of genome-wide approaches identifies lncRNAs of adult neural stem cells and their progeny in vivo. Cell Stem Cell 12:616-628. CrossRef Medline

Robel S, Berninger B, Gotz M (2011) The stem cell potential of glia: lessons from reactive gliosis. Nat Rev 12:88-104. CrossRef Medline

Serrano M, Lee H, Chin L, Cordon-Cardo C, Beach D, DePinho RA (1996) Role of the INK4a locus in tumor suppression and cell mortality. Cell 85:27-37. CrossRef Medline

Utikal J, Polo JM, Stadtfeld M, Maherali N, Kulalert W, Walsh RM, Khalil A, Rheinwald JG, Hochedlinger K (2009) Immortalization eliminates a roadblock during cellular reprogramming into iPS cells. Nature 460: 1145-1148. CrossRef Medline

Ventura A, Meissner A, Dillon CP, McManus M, Sharp PA, Van Parijs L, Jaenisch R, Jacks T (2004) Cre-lox-regulated conditional RNA interference from transgenes. Proc Natl Acad Sci U S A 101:10380-10385. CrossRef Medline

Vierbuchen T, Wernig M (2012) Molecular roadblocks for cellular reprogramming. Mol Cell 47:827-838. CrossRef Medline

Vierbuchen T, Ostermeier A, Pang ZP, Kokubu Y, Südhof TC, Wernig M (2010) Direct conversion of fibroblasts to functional neurons by defined factors. Nature 463:1035-1041. CrossRef Medline

Zhang Y, Barres BA (2010) Astrocyte heterogeneity: an underappreciated topic in neurobiology. Curr Opin Neurobiol 20:588-594. CrossRef Medline

Zhou Q, Melton DA (2008) Extreme makeover: converting one cell into another. Cell Stem Cell 3:382-388. CrossRef Medline 